\title{
HUBUNGAN ANTARA INTENSITAS MENJALANKAN DZIKIR NAFAS DENGAN LATENSI TIDUR
}

\author{
Setiyo Purwanto \\ Fakultas Psikologi Universitas Muhammadiyah Surakarta \\ Sp236@ums.ac.id
}

\begin{abstract}
Sleep latency is the time period between preparation for sleep and sleep real early. Sleep latency is the main indicator to determine the quality of one's sleep. The longer the latency of sleep needed someone to fall asleep, the quality of one's sleep is also lower. Dhikr breath is an alternative method of therapy in order to reduce the latency of sleep a person so that better quality sleep. In remembrance breath of relaxation and transcendental meditation are effective to make relax and eventually fall asleep. The purpose of this study was to determine the relationship between the intensity of the run dhikr breath with sleep latency. This study was an observational study with cross sectional approach. Subjects were pilgrim dhikr breath as much as 21 respondents. Data dhikr intensity of breath and sleep latency obtained by filling the questionnaire. The results showed that the intensity of breath dhikr average respondent is 81,14 times, while the average sleep latency was 13,05 minutes. Analysis of the relationship is done by Wilcoxon Signed Ranks test showed a p-value $=0,00$, it indicates that there is a very significant correlation between the intensity of breath dhikr with sleep latency. The higher the intensity of the dhikr of one's breath, the lower the latency sleep.
\end{abstract}

Keyword : Intensity, dhikr breath, latency, sleep

\begin{abstract}
Abstraksi. Latensi tidur adalah periode waktu antara persiapan untuk tidur dan awal tidur yang sebenarnya. Latensi tidur merupakan indikator utama untuk menentukan kualitas tidur seseorang. Semakin lama latensi tidur yang diperlukan seseorang untuk tertidur maka kualitas tidur seseorang tersebut juga semakin rendah. Dzikir nafas merupakan sebuah alternatif metode terapi untuk dapat mengurangi latensi tidur seseorang sehingga kualitas tidurnya lebih baik. Dalam dzikir nafas terdapat relaksasi dan meditasi transendental yang efektif untuk membuat relaks dan akhirnya tertidur. Tujuan penelitian ini adalah untuk mengetahui hubungan antara intensitas menjalankan dzikir nafas dengan latensi tidur. Penelitian ini merupakan penelitian observasional dengan pendekatan cross-sectional. Subjek penelitian adalah jamaah dzikir nafas sebanyak 21 responden. Data intensitas dzikir nafas dan latensi tidur diperoleh melalui pengisian kuisioner. Hasil penelitian menunjukkan bahwa skor intensitas dzikir nafas rata-rata responden adalah 81,14 sedangkan latensi tidur rata-rata adalah 13,05 menit. Analisis hubungan dilakukan dengan uji Wilcoxon Signed Ranks test menunjukkan nilai $p=0,00$, hal ini menunjukkan bahwa terdapat hubungan yang secara sangat signifikan antara intensitas dzikir nafas dengan latensi tidur. Semakin tinggi intensitas melakukan dzikir nafas seseorang maka semakin rendah latensi tidurnya.
\end{abstract}

Kata kunci : Intensitas, dzikir nafas, latensi, tidur

\section{PENDAHULUAN}

Tidur adalah suatu fenomena biologis yang terkait dengan irama alam semesta, irama sirkadian yang bersiklus 24 jam, terbit dan terbenamnya matahari, waktu malam dan siang hari, tidur merupakan kebutuhan manusia yang teratur dan berulang untuk menghilangkan kelelahan jasmani dan kelelahan mental (Panteri, 1993). Kuantitas dan kualitas tidur seseorang dipengaruhi oleh beberapa faktor yaitu usia, aktifitas fisik, stres psikologis (penyakit dan situasi yang menyebabkan stres), motivasi, kebudayaan, diet, konsumsi alkohol, merokok, konsumsi 
kafein, lingkungan, gaya hidup, penyakit, serta pengobatan (Taylor et al, 1997). Kualitas tidur seseorang tidak tergantung pada jumlah atau lama tidur seseorang, tetapi bagaimana pemenuhan kebutuhan tidur orang tersebut. Indikator tercukupinya pemenuhan kebutuhan tidur seseorang adalah kondisi tubuh waktu bangun tidur, jika setelah bangun tidur merasa segar berarti pemenuhan kebutuhan tidur telah tercukupi (Potter \& Perry,2006).

Kurang tidur dapat membahayakan bagi diri kita maupun orang lain. Seseorang yang kurang tidur lalu mengemudi mobil sendiri sering mengalami kecelakaan fatal. Kurang tidur dapat pula mengakibatkan masalah dalam keluarga dan perkawinan, karena kurang tidur dapat membuat orang cepat marah. Selain itu kurang tidur juga dapat menjadikan lebih sulit diajak bergaul dengan orang lain (Parmet, 2003). Bila tidur kurang lelap, maka kita akan merasa letih, lemah, dan lesu pada saat bangun. Kehilangan jam tidur meskipun sedikit mempunyai akibat yang sangat bagi semangat, kemampuan konsentrasi, kinerja, produktivitas, ketrampilan komunikasi, dan kesehatan secara umum, termasuk sistem gastrointestinal, fungsi kardiovaskular dan sistem kekebalan tubuh (Mass, 1998).

Orang yang tidak tidur menyebabkan orang kehilangan energi dan cepat marah. Seseorang yang selama dua hari tidak tidur akan sulit berkonsentrasi untuk waktu yang lama. Banyak kesalahan akan dibuat, terutama dalam tugas-tugas rutin seharihari, dan kadang orang tersebut tidak mampu memusatkan perhatian. Orang yang tidak tidur lebih dari tiga hari akan sulit berpikir, melihat, dan mendengar dengan jelas. Beberapa orang akan mengalami periode halusinasi, yaitu mereka melihat hal-hal yang sebenarnya tidak ada. Hasil tes memperlihatkan setelah seseorang tidak tidur selama empat hari, ia hanya dapat melakukan sedikit tugas rutin.
Tugas-tugas yang menuntut perhatian atau bahkan kegesitan mental yang minimum, akan menjadi sulit ditangani. Setelah empat setengah hari ada gejala mengigau, dan dunia di sekelilingnya menjadi sangat aneh di matanya (Mass, 1998). Hal ini menunjukkan bahwa kurang tidur akan menurunkan produktivitas dan prestasi kerja seseorang.

Morin (1992) mengungkapkan bahwa gangguan tidur seperti insomnia dapat mempengaruhi suasana hati, efisiensi dalam menyelesaikan tugas, dan kemampuan sosial. Penemuan Ferber yang ditulis Morin (1992) menyebutkan bahwa sedikitnya kuantitas tidur, lebih banyak dikeluhkan oleh wanita, mereka yang pada usia dewasa akhir, dan mereka yang memiliki pendidikan serta tingkat sosial yang rendah. Selanjutnya Morin (1992) menyebutkan hampir setiap manusia pernah mengalami masalah tidur. Satu dari tiga orang dilaporkan mengalami gangguan tidur dan satu dari sembilan orang memiliki masalah tidur yang cukup serius. Karena beberapa masalah tidur dapat diatasi oleh individu yang bersangkutan dan yang lain memerlukan bantuan dokter, maka diagnosis diri (self diagnosis) menjadi sangat penting.

Kesulitan tidur atau insomnia adalah keluhan tentang kurangnya kualitas tidur yang disebabkan oleh satu dari: (1) sulit memasuki tidur, (2) sering terbangun malam kemudian kesulitan untuk kembali tidur, (3) bangun terlalu pagi, dan (4) tidur yang tidak nyenyak. Insomnia tidak disebabkan oleh sedikitnya seseorang tidur, karena setiap orang memiliki jumlah jam tidur sendirisendiri. Tapi yang menjadi penekanan adalah akibat yang ditimbulkan oleh kurangnya tidur pada malam hari seperti kelelahan, kurang gairah, dan kesulitan berkonsentrasi ketika beraktivitas (Edinger, 2000).

Beberapa literatur menyebutkan bahwa selain KIE terapi insomnia bisa bersifat 
farmakologis maupun non-farmakologis. KIE diterapkan dengan mengoptimalkan pola tidur yang sehat pada penderita. Terapi farmakologis maupun non-farmakologis berfokus pada identifikasi faktor penyebab untuk mengontrol dan mengelola masalah yang mendasari terjadinya insomnia. Pada kebanyakan kasus insomnia kronik dapat disembuhkan jika penyebab medis atau psikiatri dievaluasi dan diobati dengan benar (Edinger et al, 2001, Daniel, 2008). Daniel (2008) mengungkapkan bahwa terapi non farmakologi terdiri dari sleep hygine, sleep retriction atau pembatasan tidur, relaxation therapy atau terapi relaksasi dan stimulus control therapy.

Penelitian-penelitian sebelumnya tentang gannguan tidur lebih terfokus pada penerapan program terapi relaksasi dalam berbagai bentuk untuk mengatasi gannguan tidur. Dengan program terapi relaksasi dapat mengkondisikan seseorang mencapai kondisi relaks sehingga seseorang lebih mudah untuk mengawali tidur (Davis et al, 1995; Benson, 2000; Purwanto, 2004). Kekurangan dari program relaksasi ini adalah dibutuhkan waktu dan pemandu khusus untuk melaksanakan terapi. Terapi lain yang bisa diterapkan untuk mengatasi gangguan tidur adalah terapi dzikir. Apabila dibandingkan dengan dengan terapi relaksasi, dzikir lebih mudah dilakukan sseorang untuk memasuki waktu tidur karena merupakan aktivitas religius yang rutin dilaksanakan seseorang setiap waktu dan setiap saat.

Dzikir sebagai salah satu bentuk ibadah dalam agama Islam merupakan relaksasi religius, dengan mengucapkan lafadz Allah atau Ahad secara terus menerus dengan pelan dan ritmis akan dapat menimbulkan respon relaksasi (Benson, 2000; Sangkan 2002). Pengulangan lafadz tersebut disertai dengan keyakinan terhadap kasih sayang-Nya, perlindungan-Nya dan sifat-sifat baik-Nya yang lain akan menimbulkan rasa tenang dan rasa aman.

Dzikir yang dipadukan dengan kalimat kalimat ritmis dapat memicu efek relaksasi. Pengulangan tersebut harus disertai dengan sikap pasif terhadap rangsang baik dari luar maupun dari dalam. Sikap pasif dalam konsep religius dapat diidentikan dengan sikap pasrah kepada Tuhan. Sikap pasrah inilah yang dapat melipatgandakan respon relaksasi yang muncul. Efek relaksasi ini dapat menimbulkan keadaan tenang (Sangkan, 2002; Aemilianus, 2012). Perpaduan antara dzkir dan nafas akan membuat keadaan relaks yang semakin dalam dapat menimbulkan relaksasi secara mendalam sehingga dapat mengurangi gangguan insomnia. Dalam penelitian ini yang dilihat salah satu bagian dari ciri insomnia yaitu durasi latensi tidur. Latensi tidur dapat menjadi indikator sejauh mana kualitas tidur seseorang.

\section{METODE PENELITIAN}

Penelitian ini merupakan penelitian dasar untuk menguji keefektifan dzikir nafas dalam meningkatkan kualitas tidur terutama latensi tidur. Jenis penelitian ini adalah observasional dengan pendekatan cross-sectional. Subjek penelitian ini adalah jamaah dzikir nafas berjumlah 21 orang terdiri dari 2 perempuan dan 19 orang laki-lakidi. Penelitian dilaksanakan yang Padepokan Patrap Surakarta pada saat jamaah dzikir nafas melaksanakan pertemuan bulanan.

Variabel yang dikumpulkan dalam penelitian ini adalah intensitas dzikir nafas dan latensi tidur. Intensitas dzikir nafas diperoleh melalui pengisian kuesioner yang kemudian diolah dalam bentuk. Latensi tidur dihitung berdasarkan waktu yang dibutuhkan 
seseorang untuk mengawali tidur. Analisis hubungan dilakukan dengan uji Wilcoxon Signed Ranks test.

\section{HASIL DAN PEMBAHASAN}

\section{Intensitas Dzikir Nafas}

Dzikir adalah menyadari Allah, yaitu Allah yang dekat, Allah yang Maha Meliputi Segala Sesuatu atau Al-Muhiith. Dzikir yang benar adalah dzikir dengan kesadaran, bukan dzikir dengan pikiran. Jadi makna dzikir adalah 'sadar Allah', bukan 'mengingat Allah' atau 'ingat Allah'. Dzikir adalah Ruhnya ibadah. Jadi, kalau dalam suatu ibadah tidak ada dzikir-nya, maka tidak ada ruh di dalam ibadah itu. Atau, ibadah itu tidak ada maknanya. Kalau dalam shalat, sangat jelas sekali ancaman Allah untuk mereka yang tidak memiliki ruh dalam ibadahnya, seperti yang disebutkan dalam surat Al-Ma'un ayat 4-5, bahwa celakalah orang yang lalai dalam shalatnya ( Purwanto, 2012).

Dzikir nafas adalah Dzikir kesadaran dengan menggunakan lafaz 'Huu Allah', sebuah metode dzikir dengan mengikuti irama keluar-masuknya nafas melalui rongga hidung sampai ke paru-paru, dan kemudian dihembuskan melalui rongga hidung lagi. Cara mempraktikkannya juga sangat mudah, yakni ketika menghirup udara, hati ber-dzikir 'Huu' (yang artinya Dia, Allah), dan ketika mengeluarkan nafas, hati ber-dzikir 'Allah'. Amaliah dzikir merupakan jenis amal yang paling mudah dan paling ringan. Namun, karena amalan ini menuntut ke-istiqamah-an (baca konsisten, secara terus-menerus) dan keterlibatan pikiran dan emosi, maka amalan ini menjadi berat (Purwanto, 2012).

Dzikir nafas adalah suatu metode untuk dapat berdzikir kepada Allah 24 jam nonstop. Seperti halnya dengan metode iqro yang dilakukan atau dipelajari agar orang dapat membaca huruf di dalam al Quran. Jadi metode bukanlah tujuan, yang menjadi tujuan adalah agar kita dapat melaksanakan perintah Allah dan Rasulnya dengan lebih baik. Karena dzikir nafas adalah metode maka tidak akan pernah ditemukan tuntunan quran dan hadis yang terang-terangan memerintahkan kita untuk melakukan dzikir nafas. Tapi perintah untuk berdzikir sebanyak banyaknya akan banyak ditemukan (Purwanto, 2012).

Intensitas dzikir nafas pada penelitian ini diperoleh melalui penjumlahan skor jawaban dari 20 pertanyaan pada kuisioner. Pertanyaan yang diajukan meliputi frekuensi melakukan dzikir nafas, cara melakukan dzikir nafas, pengalaman pribadi yang dirasakan ketika melakukan dzikir nafas, manfaat yang dirasakan setelah melakukan dzikir nafas dan semangat untuk melaksanakan dzikir nafas. Hasil penelitian menunjukkan bahwa intensitas dzikir nafas subjek minimal adalah 55 dan maksimal 98 dengan intensitas ratarata adalah $81,14 \pm 12,11$. Gambaran lebih jelas tentang intensitas dzikir nafas subjek dapat dilihat pada Tabel 1 di bawah ini:

Tabel 1. Distribusi Intensitas Dzikir Nafas

\begin{tabular}{lcc}
\hline $\begin{array}{c}\text { Intensitas Dzikir } \\
\text { Nafas }\end{array}$ & $\begin{array}{c}\text { Jumlah } \\
\text { (orang) }\end{array}$ & $\begin{array}{c}\text { Prosentase } \\
(\mathbf{\%})\end{array}$ \\
\hline Baik & 10 & 47.6 \\
Sedang & 7 & 33.3 \\
Kurang & 4 & 19.0 \\
Total & 21 & 100.0 \\
\hline
\end{tabular}

Tabel 1 menunjukkan bahwa hampir separuh subjek mempunyai intensitas dzikir nafas yang baik. Hal ini menunjukkan bahwa dzikir nafas telah menjadi kebiasaan mereka sehari-hari.

\section{LatensiTidur}

Menurut kamus kesehatan latensi tidur (sleep latency) didefinisikan sebagai 
periode waktu antara persiapan untuk tidur dan awal tidur yang sebenarnya.Latensi tidur merupakan indicator utama untuk menentukan kualitas tidur seseorang. Semakin lama latensi tidur yang diperlukan seseorang untuk tertidur maka kualitas tidur seseorang tersebut juga semakin rendah. Beberapa faktor yang diduga mempengaruhi latensi tidur adalah faktor fisiologis tubuh, faktor psiklogis seperti kecemasan dan ketegangan serta faktor lingkungan.

Pada penelitian ini latensi tidur diperoleh dengan pengisisan kuesioner, subjek diminta untuk menghitung berapa waktu rata-rata yang dibutuhkan dari persiapan tidur sampai subjek mengawali tidur yang sebenarnya. Hasil penelitian menunjukkan bahwa sleep latency subjek minimal adalah 2 jam, maksimal 30 jam dengan rata-rata 13,05 $\pm 9,59$ jam. Hal ini menunjukkan bahwa sleep latency jamaah dzikir nafas rata-rata termasuk dalam kondisi cukup. Gambaran lengkap sleep latency subjek dapat dilihat pada Tabel 2.

Tabel 2. Distribusi Latency Tidur Subjek

\begin{tabular}{lcc}
\hline $\begin{array}{c}\text { Latensi Tidur } \\
\text { Subjek }\end{array}$ & $\begin{array}{c}\text { Jumlah } \\
\text { (Jam) }\end{array}$ & $\begin{array}{c}\text { Prosentase } \\
\text { (\%) }\end{array}$ \\
\hline Baik & 13 & 61.9 \\
Cukup & 4 & 19.0 \\
Kurang & 4 & 19.0 \\
Total & 21 & 100.0 \\
\hline
\end{tabular}

Tabel 2 menunjukkan bahwa separuh lebih subjek memiliki latency tidur yang baik. Hal ini karena jamaah telah tebiasa melakukan dzikir nafas yang rutin. Menurut pendapat merekal pengaruh positif telah mereka rasakan diantaranya berkurangnya kecemasan dan ketegangan dalam melakukan berbagai aktivitas termasuk tidur.

\section{Hubungan Intensitas Dzikir Nafas dengan Latensi Tidur}

Teknik dzikir nafas dapat membantu mengurangi jumlah latensit idur. Dzikir nafas merupakan metode pengendoran otot dengan cara mengikuti nafas dan membiarkan seluruh otot untuk relaks. Pengendoran otot seperti yang terjadi pada relaksasi progresif yaitu pengendoran menyeluruh kesemua tubuh yang diawali dengan mengikuti nafas kemudian menyebar keseluruh tubuh. Keadaan ini juga akan menstimulasi otak untuk relaks sehingga dapat membawa seseorang untuk lebih mudah mencapai relaks dan keadaan mengantuk.

Tabel 3 menunjukkan bahwa pada subjek yang mempunyai intensitas dzikir nafasnya baik $60 \%$ subjek tersebut cenderung mempunyai latensi tidur yang baik, demikian pula pada subjek dengan intensitas dzikir nafasnya sedang $71,4 \%$ subjek cenderung mempunyai latensi tidur yang baik pula. Akan tetapi pada subjek dengan intensitas dzikir nafasnya kurang 25\% diantaranya cenderung mempunyai latensi tidur yang kurang baik .Hal ini menunjukkan bahwa intensitas dzikir nafas mempunyai peran terhadap latensi tidur seseorang.

Tabel 3. Distribusi Latensi Tidur Menurut Intensitas Dzikir Nafas

\begin{tabular}{|c|c|c|c|c|}
\hline \multirow[t]{2}{*}{$\begin{array}{c}\text { Intensitas } \\
\text { Dzikir Nafas } \\
\text { Subjek }\end{array}$} & \multicolumn{3}{|c|}{$\begin{array}{c}\text { Latensi } \\
\text { Tidur Subjek }\end{array}$} & \multirow[t]{2}{*}{ Total } \\
\hline & Baik & Cukup & Kurang & \\
\hline \multirow[t]{2}{*}{ Baik } & 6 & 2 & 2 & 10 \\
\hline & $60.0 \%$ & $20.0 \%$ & $20.0 \%$ & $100.0 \%$ \\
\hline \multirow[t]{2}{*}{ Sedang } & 5 & 1 & 1 & 7 \\
\hline & $71.4 \%$ & $14.3 \%$ & $14.3 \%$ & $100.0 \%$ \\
\hline \multirow[t]{2}{*}{ Kurang } & 2 & 1 & 1 & 4 \\
\hline & $50.0 \%$ & $25.0 \%$ & $25.0 \%$ & $100.0 \%$ \\
\hline
\end{tabular}


Hasil analisis hubungan dilakukan dengan uji Wilcoxon Signed Ranks test menunjukkan nilai $\mathrm{p}=0,00$ dengan nilai $\mathrm{Z}=-4,016$. Hal ini menunjukkan bahwa terdapat hubungan yang sangat signifikan antara intensitas dzikir nafas dengan latensi tidur, semakin tinggi intensitas melakukan dzikir nafas seseorang maka semakin rendah latensi tidurnya.

Dalam literatur psikologi salah satu terapi perilaku (behavior therapy) adalah terapi relaksasi (Dewi, 1998). Terapi ini sudah banyak digunakan baik untuk penurunan ketegangan, atau mencapai kondisi tenang (Utami, 1993). Demikian juga penelitian yang dilakukan oleh Jacobson dan Wolpe menunjukkan bahwa relaksasi dapat mengurangi ketegangan dan kecemasan (Wallace, 1971. Beech dkk, 1982).

Relaksasi merupakan pengaktifan dari syaraf parasimpatetis yang menstimulasi turunnya semua fungsi yang dinaikkan oleh sistem syaraf simpatetis, dan menstimulasi naiknya semua fungsi yang diturunkan oleh syaraf simpatetis. Masing-masing syaraf parasimpatetis dan simpatetis saling berpengaruh maka dengan bertambahnya salah satu aktivitas sistem yang satu akan menghambat atau menekan fungsi yang lain (Utami, 1993). Ketika seseorang mengalami gangguan tidur maka ada ketegangan pada otak dan otot sehingga dengan mengaktifkan syaraf parasimpatetis dengan teknik relaksasi maka secara otomatis ketegangan berkurang sehingga seseorang akan mudah untuk masuk ke kondisi tidur.
Dzikir nafas memberikan efek relaksasi dengan dua alasan yang pertama adalah dengan mengikuti nafas dan yang kedua ada dengan mengulang kata sesuai dengan keluar masuknya nafas. Menurut Benson (2000) formula-formula tertentu yang dibaca berulang-ulang dengan melibatkan unsur keimanan kepada agama, kepada Tuhan yang disembah akan menimbulkan respon relaksasi yang lebih kuat dibandingkan dengan sekedar relaksasi tanpa melibatkan unsur keyakinan terhadap hal tersebut. Dzikir nafas dapat mengaktifkan unsur spiritual (faith factor), dengan menyebut Huu setiap nafas masuk dan menyebut Allah setiap nafas keluar. Kata Huu dan Allah dalam dzikir nafas di arahkan kepada Allah yang menguasai alam semesta, dapat memberikan efek keberserahan kepada Allah sehingga secara mental dapat memberikan rasa tenang.

\section{SIMPULAN}

Hasil penelitian ini mengindikasi bahwaHal ini menunjukkan bahwa intensitas dzikir nafas mempunyai peran terhadap latensi tidur seseorang. Terdapat hubungan yang sangat signifikan antara intensitas dzikir nafas dengan latensi tidur, semakin tinggi intensitas melakukan dzikir nafas seseorang maka semakin rendah latensi tidurnya. Dzikir nafas dapat digunakan sebagai salah satu metode untuk meningkatkan kualitas tidur.

\section{DAFTAR PUSTAKA}

Beech, H.R., Burn, L.E., \& Sheffield, B,F., (1982). A Behavioral Approach to the Management of Stress: A Practical Guide to Techniques. New York: John Willey and Sons.

Benson, H.M.D., (2000). Dasar-dasar Respon Relaksasi: Bagaimana menggabungkan respon Relaksasi dengan Keyakinan Pribadi Anda (terjemahan). Bandung: Mizan ., (2000). Respon Relaksasi: Teknik Meditasi Sederhana dan Untuk Mengatasi Tekanan Hidup (terjemahan). Bandung: Mizan 
Daniel J. B, (2008). Cronic Insomnia. The American Journal of Psychiatry 165 (6). 678-686

Dewi, C., (1998). Efektifitas Pelatihan Relaksasi untuk Mengurangi Ketegangan Terbang pada Siswa Sekolah Penerbang. Skripsi (tidak diterbitkan). Yogyakarta: Fakultas Psikologi UGM.

Edinger. J.D., Sullivan. R.H., Victor, G., Michael, D., Dorothy, V., \& Diane,. (2000). Insomnia and the Eye of the Beholder: Are There Clinical Markers of Objective Sleep Disturbances Among Aduls with and Without Insomnia Complaints?. Journal of Consulting and Clinical Psychology. 68. (4). 586-593.

Edinger.J.D, Wohlgemuth, W.K., Radtke, R.A., Marsh, G.R., \& Quillian, R.E. (2001). Cognitive behavioral therapy for treatment of cronic primary insomnia. Journal of American Medical Association (JAMA). 285 (14). 1856-1864

Espie. C.A. (2002). Insomnia: Conceptual Issue in the Development, Persistence, and Treatment of Sleep Disorder in Adult. Annual Reviews 53. 215-43

Liu, X., Uchiyama, M., Kim, K., Okawa, M., Shibui, K., Kudo, Y., Doi, Y., Minowa, M., \& Ogihara, R. (2000). Sleep Loss and Day Time Sleepiness in the General Adult Population of Japan. Psychiatric research. 93(1).1-11

Purwanto, S. (2012). Dzikir Nafas. Solo: Romiz aisy.

Sangkan, A. (2002). Berguru Kepada Allah. Jakarta: Bukit Thursina.

Schenck, C H. Mahowald, M. Sack, R., (2003), Assesment and Management of Insomnia. Journal of American Medical Association (JAMA). 289 (19). 2475-2479

Utami, M.S. (1993). Prosedur Relaksasi. Yogyakarta: Fakultas Psikologi UGM

Wallace, R.K. Benson, H., \& Wilson, A. F. (1971). A Wakeful Hypometabolic Physiologic State. American Journal of Physiology. 221 (3). 795-799 